the early appearance of this comet and Donati's Comet of 1858. Thus, Donati's Comet showed a dark division between the two principal tail streamers, and this feature was very pronounced in 1941c. The envelopes or caps were also very similar in both comets, and the shapes of most of these could be very satisfactorily represented by catenaries. In all these cases the departure from a catenary was in the sense that the observed curve was less divergent near its open end than was the catenary that fitted it best near its vertex.

This departure should indicate that the velocity of outflow from the nucleus of the matter forming these envelopes was steadily increasing, on the fountain theory of the formation of these caps, outlined by Eddington in Mon. Not. Roy. Astro. Soc., $70,442(1910)$. It is remarkable, however, that the linear size of the caps did not increase from day to day, as would be expected on the fountain theory, which indicates that the velocity of outflow from the nucleus of the matter forming the envelopes should steadily increase. From January 20 until 28, the date of perihelion, the inner caps grew brighter as they got smaller, but there is not the same amount of evidence available for the outer caps. What there is shows that these outer caps seem to have remained much about the same size, or in some cases to have expanded slightly before starting to contract.

A full description is given of the phenomena visible on the plates for each day when photographs were taken.

\section{FIDDLER CRABS}

$\mathbf{J}^{\mathrm{o}}$ CELYN CRANE has made important and interesting observations on these crabs ("Crabs of the Genus Uea from the West Coast of Central America." Eastern Pacific Expeditions of the New York Zoological Sotiety. XXVI. Zoologica, 26, Part 3; Oct. 31, 1941). The present paper deals with specimens taken on the Arcturus Oceanographic Expedition (1925), on the Eastern Pacific Zaca Expedition (1937-1938) and on a special trip made to the Pacific shores of Panama by Miss Crane herself in January and February 1941.

The studies of habits and behaviour made on this last trip embrace a large amount of new knowledge on the ecology and especially the courtship display and mating of these crabs. Twenty-seven species are accurately described, eleven being new to science. There have been different opinions about the meaning of the waving of the large claw in fiddler crabs, but it is quite definitely established by these observations that this waving of the large claw, at any rate in the region investigated, is primarily for the attraction of the female, at least during the breeding season, and only secondarily for the warning off of crabs trespassing on a male's feeding range. This waving is only a part, or step, in a definite courtship display or dance which varies so greatly with the species that individuals can be recognized at a distance by their characteristic motions.

The patience which such studies necessitate is enormous, whole periods between tides being utilized and individual crabs kept under observation for many hours. The quality and quantity of the results show that such patience is amply rewarded, and Miss Crane is to be congratulated on the completion of a valuable contribution to the study of crab behaviour. Detailed colour notes are also given of all the crabs described; these colours vary enormously at the breeding season and at the time of display. "Courting adult males, in contrast to other adult males, and, of course, to females and young, change colour daily upon exposure to sunlight within the space of a short time-a few minutes to an hour or more being required. . . . That courtship coloration and display play a definite part in sexual recognition is certain, that they play one also in sexual selection is likely, but has not yet been proved by experiment."

A phylogenetic tree of the species dealt with is suggested and a key given to the species of Uca occurring on the west coast of America and in the Galapagos Islands.

\section{NATIVE SUBSISTENCE ON THE AMERICAN CENTRAL PLAINS}

TN a recent paper, W. R. Wedel dealt with man's 1 battle against Nature in the great plains of Kansas and Nebraska (Smithson. Misc. Coll., 101, No. 3: "Environment and Native Subsistence Economics in the Central Great Plains". Publ. 3639. Pp. $\mathrm{ii}+29+5$ plates. Washington, D.C.: Smithsonian Institution, 1941.) This region of widespread droughts, dust-storms, and consequent crop failures has been for some centuries the scene of attempted cultivation-sometimes successful, sometimes not. In view of recent failures the author has been collecting archæological evidence which tends to show that the aboriginal groups that exploited this region at various times and in various ways were themselves faced with similar adverse climatic conditions. In the western portion of this territory lies part of the High Plains province and immediately eastward of this is a stretch of sandy country now used for cattle rearing as the loose sandy soil renders it impracticable for agriculture on a large scale. Before the advent of the white man all this portion was roamed over by herds of bison, followed by nomadic tribes of Indians who preyed on them and on other abundant game. But farther east there is the great loess plain, fertile and well suited to agriculture and which was formerly inhabited by groups of Indians who cultivated the soil and made semi-permanent settlements. That these never became permanent was probably owing to the recurrent bad seasonsmainly droughts - that then, as now, might last for some years.

Archæological evidence goes to prove that groups of people did succeed at times in wresting a living even in the more inhospitable zones of the dry belt; as proved by sites containing the remains of charred corn and bone hoes, together with such quantities of animal bones as suggest that hunting was the main economy and horticulture a side line. In these circumstances the vagaries of the weather would play a less important part than in a wholly agricultural community. Droughts undoubtedly occurred in prehistoric times, the dust storms that accompanied them forming deposits over the sites.

In historic times great droughts occurred causing large population movements of the white settlers and reducing the Indians to the borderland of starvation. But it must be borne in mind that the old cultural patterns of the Indians were already broken by 
contact with the whites and they had not had sufficient time to re-adapt themselves. It is likely that in pre-white times they might have weathered these droughts as they were of comparatively short duration, although severe.

The author came to the conclusion that it is unlikely that any major climatic change has taken place in the central great plains within the last thousand years, and that alternate settlement and abandonment of this area was as true of primitive man as it is of white man's tenure when large-scale government aid has not come to his rescue.

\section{EARTHQUAKE ORIGINS IN THE NEW ZEALAND REGION}

$\mathrm{R}$ C. HAYES, acting director of the Dominion Observatory, Wellington, New Zealand, has been investigating the origins of earthquakes in New Zealand ("Earthquake Origins in the New Zealand Region". Dominion Observatory Bulletin No. S.62). Using new material and improved methods, Hayes has redetermined the epicentres and depths of focus of several earthquakes in the New Zealand region for the years 1931 and 1936-40 inclusive, and has prepared a map showing these epicentres.

From these results it is evident that while the general distribution of earthquake epicentres does not differ appreciably from that indicated in earlier years, the more recent results bring out certain features which were not evident before. For example, the extensive seismic region, covering the eastern and southern parts of the North Island, Cook Strait area, and the northerm part of the South Island is seen to have a sharply defined boundary on its north-west side, concave towards the north-west. It crosses the North Island from the Bay of Plenty to the region north of Cape Farewell, and there are very few earthquakes to the north-west of this line. Deep focus earthquakes may be significant.

Many of the shocks originating in the Gisborne East Cape region and farther eastward have focal depths greater than normal. Origins at depths of $60 \mathrm{~km}$. or more are common in the northern Hawke's Bay and Gisborne regions, the depths tending to increase up to about $100 \mathrm{~km}$. for the submarine shocks farther eastward. Shocks originating in the south-west of South Island also have depths of focus of nearly $100 \mathrm{~km}$. An isolated origin deeper than normal has been located near the north-eastern extremity of South Island $(80 \mathrm{~km}$.).

There is another zone, marked by origins at depths ranging up to $300 \mathrm{~km}$. or more, which extends from near White Island in the Bay of Plenty to the region of Lake Taupo, a zone corresponding very closely with that in which volcanic activity occurs. The greatest depth of origin so far recorded in this zone is $320 \mathrm{~km}$. (nearly 200 miles).

An important feature regarding the distribution of deep shocks which is indicated by the present results is their location with respect to the normal shocks in their vicinity. In most regions around the Pacific, deep-focus shocks tend to congregate away from the Pacific, the normal shocks being located on the Pacific side of them. This is clearly the case in the North Island of New Zealand, where the deep-focus zone has an extensive region of shallower or normal shocks to eastward of it.

\section{FORTHCOMING EVENTS}

(Meeting marked with an asterisk is open to the public.)

\section{Monday, February 2}

ROTAL Society of ARTS (at John Adam Street, Adelphi, London, W.C.2), at 1.45 p.m.-Dr. B. A. Keen, F.R.S. : "Soil Physics, Theory and Practice" (Cantor Lectures, III). ROYAL GEOGRAPHICAL SocIETY (at Kengington Gore, London,
s.W.7), at 3 p.m.-Dr. G. H. C. Hart: "Recent Development in the Netherlands Indies".

\section{Wednesday, February 4}

Royal Soolety of ARTs (at John Adam Street, Adelphi, London, W.C.2), at 1.45 p.m.-Mr. H. G. Jenkins : "Fluorescent Lighting".

\section{Thursday, February 5}

Royal INstitution (at 21 Albemarle Street, London, W.1), at culture"." - Prof. A. W. Ashby: "The Rise of Efficiency in Agri-

\section{APPOINTMENTS VACANT}

ApPLICATIONs are invited for the following appointments on or efore the dates mentioned

Distribution ENGINEER to the Tees Valley Water Board-The Engineer and General Manager, Water Board Offices, Corporation Road, Middlesbrough (February 5).

Chief Electrical Engineer and Manager of the Accrington Electricity Undertaking-The Town Clerk, Town Hall, Accrington (February 9).

Secretary-Steward IN ThF Department OF Pathologr aNd BAcTparology-The Secretary, Welsh National School of Medicine, 10 The Parade, Cardiff (February 10).

HEADMASTER of the King Edward VII School for Boys, Lytham-Messrs. Wilson, Wright and Wilsons, Clerks to the Governors, 6 Chapel Street, Preston, Lancs. (February 13).

MAN OR WOMAN TO TEACH MatheMatros AND MEOHANIOAL DRAWING-The Principal and Organizer of Further Education in Rugby, 61 Clifton Road, Rugby.

ASSISTANT MASTRR in the Technical School of the Royal Aircraft Establishment to teach Mathematics, Mechanics and Machine Drawing-The Central Register (ONC 745), Queen Anne's Chambers, London, S.W.1.

\section{REPORTS and other PUBLICATIONS}

\author{
(not included in the monthly Books Supplement)
}

\section{Great Britain and Ireland}

Scientiflc Proceedings of the Royal Dublin Society. Vol. 22 (N.S.) No. 46: A Strain of the Tuber Blotch Virus causing Top Necrosis in No, 46: A Strain of the Tuber Blotch virus causing Top Necrosis in Hodges, Figgis and Co., Ltd. ; London: Williams and Norgate, Ltd.) Hodges, Figgis and Co., Ltd. ; London: Williams and Norgate, Ltd.] 18. 6a. Brish Chemical Plant. 1941 Official Directory. Pp. 190. (London: British Chemical Plant Manufacturers' Association.) Gratis. [91 A Twentieth Century Economic System. Pp. 60. (London Economic Reform Club.) $6 d$. Tin Research Institute. Publication No. 107: Hot-tinning 'Difficult' Mild Steels. By W. E. Hoare and H. Plummer. Pp. 28. (Green-
ford : Tin Research Institute.) Free.

\section{Other Countries}

Smithsonian Institution : United States National Museum. Bulletin 50: The Birds of North and Middle America : a Descriptive Catalog of the Higher Groups, Genera, Species and Subspecies of Birds known to occur in North America, from the Arctic Lands to the Isthmus of Panama, the West Indies and other Islands of the Caribbean Sea, and the Galapagos Archipelago. By Robert Ridgway, continued by Herbert Friedmann. Part 9: Family Gruidae-The Cranes; Family Rallidae -The Rails, Coots and Gallinules; Family Heliornithidae-The Sungrebes; Family Eurypygidae-The Sun-bitterns. Pp. ix +254 . (Washington, D.C. : Government Printing Office.) 40 cents. [11 Smithsonian Institution: Bureau of American Ethnology. Bulletin 131: Peachtree Mound and Village Site, Cherokee County, North Carolina. By Frank M. Setzler and Jesse D. Jennings ; with Appendix Skeletal Remains from the Peachtree Site, North Carolina, by T. D Stewart. Pp. ix $+103+50$ plates. (Washington, D.C.: Government Printing office.) 40 cents.

U.S. Department of Agriculture. Farmers* Bulletin No. 1884 : U.S. Department of Agriculture. Farmers Bulletin No. 1884 : The Sugar-cane Borer. By J. W. Ingram and E. K. Bynum. Pp. ii +17. 5 cents. Technical Bulletin No. 783 : Selenium Occurrence in Certain Soils in the United States, with a Discussion of Related Topics : Sixth Report. By H. W. Lakin and H. G. Byers. Pp. 27. 5 cents. (Washing.
ton, D.C.: Government Printing Office.) 